\title{
ARQUITETURA DE TERRA EM UNIDADES AGRÍCOLAS FAMILIARES: ESTUDO DE CASO NO OESTE CATARINENSE
}

\author{
Cecília Heidrich Prompt, Msc. em Arquitetura e Urbanismo (UFSC) \\ Orientador: Wilson Jesus da Cunha Silveira, Dr. (UFSC)
}

\section{INTRODUÇÃO}

As unidades agrícolas familiares são responsáveis pela produção da maior parte dos alimentos da cesta básica brasileira e abrigam a maioria da população rural do país (BRASIL, 2009). Observa-se, entretanto, um quadro de precariedade no meio rural, que tem como conseqüência extrema a migração das famílias para as cidades. Um dos meios para o incremento da qualidade de vida no campo é a redução do déficit habitacional, com a construção de moradias que possibilitem a permanência das famílias. $\mathrm{O}$ uso materiais locais e naturais, muitas vezes disponíveis nas propriedades, pode viabilizar a construção de moradias mais adequadas ao modo de vida rural. A arquitetura de terra é aquela que utiliza o solo como matéria prima predominante.

Residência Rural em Seara - SC.

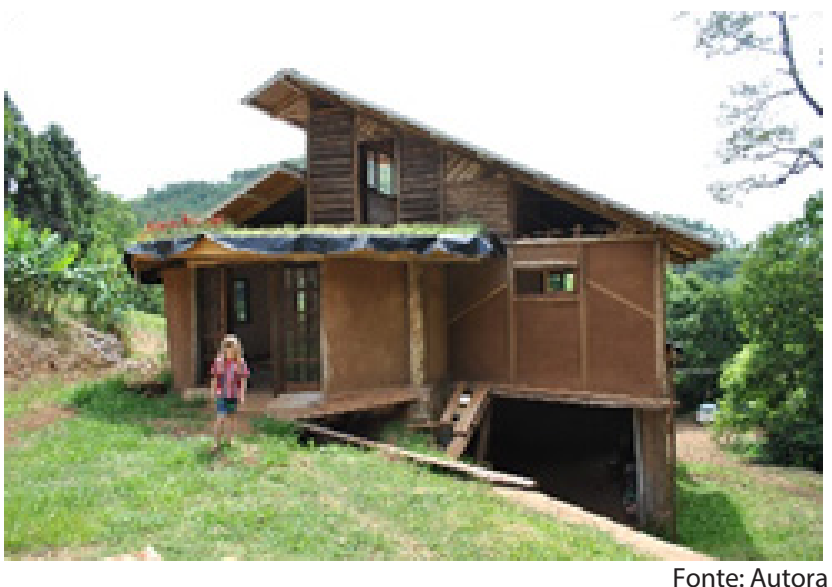

Trata-se de edificações construídas com solo estabilizado, desde que a estabilização não seja obtida pelo processo de queima (HOFFMAN, 2002). No Oeste Catarinense, existe um grupo de nove famílias que optou por construir suas moradias com o uso de tecnologias de construção com terra. A pesquisa lança um olhar sobre esta experiência, e tem como objetivo verificar se estas moradias autoconstruídas são adequadas ao seu contexto sociocultural. O trabalho tem como base um referencial teórico que faz a triangulação entre os temas agricultura familiar, habitação rural e arquitetura de terra, e utiliza métodos baseados na etnografia. A partir da descrição das edificações, é exposta a apropriação das técnicas e do espaço construído pelas famílias.

\section{METODOLOGIA}

Trata-se de uma pesquisa qualitativa. de caráter exploratório. O trabalho foi dividido em cinco etapas descritas a seguir:

Primeiramente foi feita uma pesquisa bibliográfica em três temáticas: agricultura familiar, habitação rural e arquitetura e construção com terra. Logo foi feita a delimitação do campo de pesquisa, restrito a um total de dez habitações localizadas no Oeste Catarinense para compor o estudo de caso.

Residência Rural em Descanso - SC.



A terceira etapa da pesquisa consistiu na coleta de dados em campo. As técnicas utilizadas foram: levantamento arquitetônico das edificações, observação participante e a realização de questionários e entrevistas semiestruturadas.

Para o tratamento dos dados foram realizou-se a sistematização dos questionários bem como análise das entrevistas por categorização. Estes dados foram cruzados com as observações e levantamentos arquitetônicos.

\section{RESULTADOS}

A partir da descrição das edificações, é exposta a apropriação das técnicas e do espaço construído pelas famílias. Finalmente, é realizada uma reflexão a respeito 
da satisfação dos usuários, com base nas suas percepções a respeito de conforto e segurança. Os resultados demonstram que as tecnologias utilizadas são adequadas e possibilitam a permanência das famílias no campo. Este trabalho contribuiu para o aprofundamento da realidade rural da região, com foco na habitação, assim como para a área das investigações sobre arquitetura de terra.

\section{REFEÊNCIAS}

BRASIL. Ministério do Desenvolvimento Agrário e Ministério do Planejamento, Orçamento e Gestão. Censo Agropecuário 2006. Agricultura Familiar - Primeiros Resultados. Rio de Janeiro, 2006.

HOFFMAN, Márcio. Efeito dos argilo-minerais do solo na matéria prima dos sistemas construtivos com solo cal. Dissertação apresentada ao curso de mestrado da Faculdade de Arquitetura da Universidade Federal da Bahia. Salvador, 2002. 